\title{
THE CZECH LABOUR MARKET: HISTORICAL, STRUCTURAL AND POLICY PERSPECTIVES
}

\author{
Jiří Večerník*
}

\begin{abstract}
:
A proper picture of the Czech labour market emerges by focusing on its nuanced details from various perspectives. First we focus on the specific phases of the labour market as it developed in the 1990s. Second, we observe the changing composition of the labour force and labour mobility. Third, we examine the vulnerable categories of people. Policies, active labour market policies in particular, are described in the fourth section. Fifthly, we analyse the flexibility of the labour market in its various forms. In conclusion, several questions regarding the future of the Czech labour market are raised: predominant montage character of the Czech economy and labour force, weak work commitment, growing differentiation of the labour market and a weak legal and institutional environment of business and employment.
\end{abstract}

Keywords: labour market, labour force, employment policy, Czech Republic

JEL Classification: J4, J6

The Czech labour market and labour relations developed considerably after 1989. In the initial years of economic transition, the number of redundant workers declined as many older workers entered retirement, many women returned to their families and many other employees were attracted by the service sector and self-employment. Indeed, new opportunities were opened for active people to start a business, change jobs, supplement their regular job with additional activities, and even to find work abroad. Modern skills, labour mobility and flexibility started to pay off.

In the early transition period, the situation of the labour market was more relaxed than originally expected. The reduction of the workforce, the high absorption of the tertiary sector, growing numbers of self-employed and the state support given to large companies, all contributed to the high employment rate. However, the situation changed around 1997, when many hastily privatized companies entered bankruptcy, a credit crunch emerged and worker mobility was held back. As the labour market suffered much rigidity, the army of unemployed persons sharply rose to nearly half a million people but declined again later.

* Institute of Sociology, Academy of Sciences, Czech Republic (jiri.vecernik@soc.cas.cz) This study was supported by the Grant No. 403/05/2769 from the Grant Agency of the Czech Republic for the project "The Adjustment of the Czech Labour Force: Changing Job Structures, Wage Disparities and Work Orientations". Thanks for comments and suggestions are due to Alena Nešporová, ILO Deputy Regional Director for Europe and Central Asia. 
A portrait of the Czech labour market cannot be depicted through the large brushstrokes of major successes and failures. Rather, a proper picture emerges by focusing on the more nuanced details of the labour market from various perspectives. Thus we first focus on the specific phases of the labour market as it developed in the 1990s. Second, we observe the changing composition of the labour force and labour mobility. Third, we examine the vulnerable categories of people. Policies, active labour market policies in particular, are described in the fourth section. Fifthly, we analyse the flexibility of the labour market in its various forms. We conclude by raising several open problems regarding the future of the Czech labour market.

\section{Historical Perspective: from the "Czech Miracle" to Unemployment}

After 1989, the labour market re-emerged in the transition countries of Central and Eastern Europe. In comparison with the communist period, employment has become more precarious in terms of job security, remuneration and work conditions. Some workers highly qualified in management, finance and law - have much improved job prospects. For several manual categories, relative earnings and work conditions have worsened significantly. The employment outlook appeared particularly bleak for those who held once-privileged jobs in mining and metallurgy.

Unemployment appeared in early 1990s but was strictly localized. On the contrary, in some regions (Prague), branches (construction) and educational levels (higher education, especially in economics and law), there was a shortage of workers. Active workers profited from newly opened markets; huge mobility flows evolved between the "old" and "new" sectors, testifying to the high labour commitment and capacity for alternative strategies by those workers. The relative ease with which workers become promoted caused some lack of pressure to enhance qualitative standards in job performance.

During the first years of transition, large manufacturing companies exhibited pre-privatisation behaviour supportive of labour hoarding in response to an uncertain future, sometimes called "capitalist paternalism." Ambiguous forms of cross-ownership were of particular concern: the state remained an important shareholder in large banks, which in turn controlled the most important Investment Privatisation Funds (IPFs), and through them the firms themselves. ${ }^{1}$ IPFs had incentives to maximize their allocation of capital but not to put pressure on management or to promote the restructuring of firms.

Weak corporate governance structures created economic difficulties for many firms and even led to their collapse, particularly after banks were put under hard budget constraints and radically limited their credits in 1997. The lack of micro-level restructuring, as well as the state's lack of concern for corporate transparency and governance, became apparent. The largest firms fell into financial difficulty and massive lay-offs occurred. According to an OECD study, the key reasons for the sudden increase in unemployment were the economic slowdown and more energetic steps towards firm-level restructuring, which led to deteriorating conditions in the labour market (OECD, 2000:105).

1 In this connection, David Stark (1992) referred to "recombined ownership," Lubomír Mlčoch (1995) to "state capitalism" and Ivan Szelenyi et al. to "managerial capitalism" (Eyal at al., 1998).

The term "bank socialism" is also used in the same context. 
Since the beginning of Social Democrat's rule in 1998, the privatization of companies has accelerated. Remaining state shares in banks and mines, Czech Telecom, and other distribution and communication companies were privatized. In parallel, as the role of IPFs declined, the ownership structure of the economy was gradually consolidated. Together with increasing FDI inflows, this contributed to an accelerated pace of enterprise restructuring. Reduction of the redundant staff caused the rise of unemployment, the rate of which almost doubled between 1997 and 2000 reaching 8.7\% (OECD, 2006). The economic recovery is paralleled by a decrease of unemployment up to 7\% in 2006. However, the stock of long-term employed is rising steadily, from $30 \%$ to $55 \%$ between 1997 and 2006.

\section{Structural Perspective: the Changing Composition and Mobility of the Labour Force}

Many changes have occurred under the market regime, the first being the establishment of independent work. Self-employment in communist Czechoslovakia was negligible even in comparison with Hungary and Poland. The number of entrepreneurs (together with self-employed without employees) rose very slowly until 1998, when it reached 200 thousand persons ( $4 \%$ of the employed), then stagnated, and has been declining in the 2000s. Unlike entrepreneurs, the number of self-employed increased steadily until 2003, when it reached 580 thousand persons (12\% of the employed), but has slightly declined since then.

Considerable changes were also evident in the composition of the labour force by industry and occupation. After 1989, the agriculture and manufacturing industries experienced rapid decline while the traditional tertiary sector (trade and private services) was expanding. In early 1990s, the largest employment reductions occurred in manufacturing and agriculture. The only exception was the construction industry, which maintained its strong position. The trade sector dominated the industries with increasing employment.

Despite considerable growth, the service sector in the Czech Republic is still relatively small compared to EU countries. It especially lags behind in services for manufacturing, research and development. Banking and financial services ballooned, but began to decline again in the late 1990s, after the final privatization of the banking giants. Within the tertiary sector, public administration and services for firms underwent considerable expansion, especially in comparison with the stagnating level of personnel in health services, education and research.

In conjunction with the changing composition by industry, the occupational structure has also changed. While the number of manual workers (both unskilled and skilled) declined, higher level occupations - managers, professionals and top officials expanded. For example, the number of managers and top officials increased by 70 thousand and the number of professionals (white-collar specialists) by 60 thousand workers. Occupational hierarchy is increasingly expressed in (or linked to) wage disparities.

In terms of labour mobility, there is a discrepancy in data between current LFS statistics and sociological surveys that have questioned mobility retrospectively. LFS actually started in 1993 when the "revolutionary" changes were already over, and 
covers only entries or exits to and from the labour pool and year-to-year shifts between industries. According to this source, the Czech labour market reached its turning point in 1995, when job-to-job movements amounted to almost a half million workers. Since 1997, increasing mobility started to be fuelled by the mounting numbers of employees who either became unemployed or who became economically inactive (mainly due to early retirement).

Table 1

Changes Occurred in Work Histories of Respondents between 1990 and 2005 (\%)

\begin{tabular}{|c|c|c|c|c|c|c|}
\hline \multirow{2}{*}{$\begin{array}{c}\text { Type } \\
\text { of the shift }\end{array}$} & \multicolumn{3}{|c|}{ Between 1990 and 1997} & \multicolumn{3}{|c|}{ Between 1997 and 2005} \\
\hline & Men & Women & Total & Men & Women & Total \\
\hline Entered employment & 11.2 & 8.9 & 10.0 & 14.6 & 11.3 & 12.9 \\
\hline Retired & 21.1 & 22.2 & 21.7 & 16.0 & 17.2 & 16.6 \\
\hline Changed job once & 23.4 & 23.3 & 23.3 & 26.4 & 18.5 & 22.4 \\
\hline Changed job more times & 16.5 & 10.4 & 13.2 & 15.6 & 12.3 & 13.9 \\
\hline Changed occupation once & 20.0 & 19.2 & 19.6 & 17.9 & 15.6 & 16.7 \\
\hline Changed occupation more times & 9.9 & 4.6 & 7.0 & 10.1 & 8.1 & 9.1 \\
\hline Started private business & 10.8 & 6.8 & 8.6 & 12.3 & 3.9 & 8.0 \\
\hline Promoted & 18.9 & 15.0 & 16.8 & 13.0 & 11.1 & 12.0 \\
\hline Demoted & 8.4 & 4.9 & 6.5 & 7.8 & 3.7 & 5.7 \\
\hline Lost employment once & 12.8 & 12.8 & 12.8 & 15.3 & 16.7 & 16.0 \\
\hline Lost employment more times & 4.2 & 3.5 & 3.8 & 8.8 & 4.9 & 6.8 \\
\hline \multicolumn{7}{|l|}{ Count of shifts $*$} \\
\hline 0 & 56.5 & 59.1 & 57.7 & 63.3 & 76.9 & 69.6 \\
\hline 1 & 32.7 & 32.0 & 32.3 & 30.0 & 18.4 & 24.7 \\
\hline 2 and more & 10.9 & 8.9 & 10.0 & 6.7 & 4.6 & 5.7 \\
\hline Total & 100.0 & 100.0 & 100.0 & 100.0 & 100.0 & 100.0 \\
\hline
\end{tabular}

* The summary count of shifts refers to the population currently in the labour force (excluding enters/exits) and includes only changes of jobs, occupations and employment, by controlling overlapping between one and more changes in respective types of shifts.

Source: ISSP "Work Orientations" 1997 and 2005. All persons aged 18-75.

Two sociological surveys provide us with information on individual shifts on the labour market in two periods, with 1997 as the divide (Table 1). In terms of the total number of changes, $70 \%$ persons remained stable in their jobs and worked in the second period in comparison with $58 \%$ in the first. In concrete shifts, unemployment was experienced more frequently in the second period, repeated unemployment in particular. Fewer job promotions occurred in the second period, but demotions did not increase. While fewer women entered the labour force on their own account, more men did so instead, so that the average figure has remained the same.

In contrast to job and occupational mobility, relatively little territorial mobility has emerged. This is in contrast to the expectation that migration would increase after socialist over-employment was dismantled, new job and housing opportunities were created, and job relocations became necessary. However, the very opposite has occurred in the CR: while internal migration never fell below 250 thousand persons annually 
during the 1970s and 1980s, it decreased steadily during the 1990s and hardly crossed 200 thousand migrants in the early 2000 s. $^{2}$

A major reason for the decreasing migration is the underdeveloped rental market. While the situation has been advantageous for people already housed (the tenants of former state-owned apartments in particular), the situation has become critical for young people and families obliged or willing to move. Due to continuing rent control, the black market in housing flourished. Considerable deregulation of rents should start only in 2007, due to the pressure from the Constitutional Court and the threat of large penalties the state could have to pay to residential housing owners.

\section{Unemployment Stock and Vulnerable Categories}

The unemployment stock more than doubled between 1993 and 1999, reaching 470 thousand persons by the end of 1999 (what equals 9\% unemployment rate) but later decreased steadily to 365 thousand by the end of 2006 (7\%), according to LFS. Women, particularly those up to the age of 34 , have been significantly affected. Regarding age, the unemployment rate is the lowest in pre-retirement age; both the protection of workers in pre-retirement age and frequent early retirement are probable factors. In contrast, unemployment increasingly afflicts young people, recently also including university graduates.

Looking at the composition of unemployed persons by economic sector and branch, the most exposed industries are mining and catering for men, and agriculture, trade and catering for women. Workers in the catering industry were highly exposed to labour instability and unemployment because those jobs were generally transient and were performed by a mass of unskilled people pursuing new opportunities during the transition. Since 1999, even branches of the finance sector that were spared unemployment during the economic transition have announced large lay-offs (albeit the number of redundant bank officers is less than the number of redundancies in the catering industry).

There is an increasingly negative correlation between unemployment and education. However, this general rule is counterbalanced by the high exposure of school leavers to unemployment, which is on the increase. Since October 2004, the period of study is not recognized as a basis for entitlement to unemployment benefits. According to the new arrangement, young persons who cannot find a job will be obliged to take a subsidized job. The unemployment rate of the category $15-19$ peaked at $41 \%$ and of the category $20-2414 \%$ in the end of 2006. For manual workers with only an elementary education, their lack of skills and frequent Roma ethnicity are two of the factors in their sharply rising unemployment rate.

The distribution of regional unemployment is increasingly disproportionate. Differences between regional labour markets continue to grow, both in the structure of the labour force and in the size and structure of available employment. According to the OECD computations, the average difference in unemployment rate between the worse and better performing regions was 4.7 in the CR (among 8 regions), which is similar to

2 Nevertheless, demographers suspect that a share of migration goes unrecorded as people move to unofficially rented apartments. 
Poland (among its 16 regions), but greater than in Austria, Hungary or France. However, even greater disparities in regional unemployment were identified in Italy, Spain and Germany (OECD, 2005).

Table 2

Activity and Unemployment Rates by Gender and Age in 1993-2005 (\%)

\begin{tabular}{|c|c|c|c|c|c|c|c|c|c|c|c|c|}
\hline & \multicolumn{4}{|c|}{ Men } & \multicolumn{4}{|c|}{ Women } & \multicolumn{4}{|c|}{ Total } \\
\hline & 1993 & 1997 & 2001 & 2005 & 1993 & 1997 & 2001 & 2005 & 1993 & 1997 & 2001 & 2005 \\
\hline \multicolumn{13}{|c|}{ Activity rate: } \\
\hline $15-19$ & 37.9 & 25.9 & 12.9 & 10.1 & 33.1 & 19.8 & 10.1 & 7.6 & 35.5 & 22.9 & 11.5 & 8.8 \\
\hline $20-24$ & 86.2 & 82.4 & 76.9 & 65.5 & 53.8 & 57.9 & 60.7 & 48.5 & 70.4 & 70.4 & 69.0 & 57.2 \\
\hline $25-29$ & 96.4 & 96.4 & 95.0 & 93.6 & 64.4 & 61.7 & 63.7 & 65.3 & 80.8 & 79.4 & 79.7 & 79.7 \\
\hline $30-34$ & 97.8 & 97.2 & 97.5 & 97.3 & 80.2 & 77.2 & 76.1 & 73.5 & 89.1 & 87.4 & 87.0 & 85.6 \\
\hline $35-39$ & 97.3 & 97.3 & 97.3 & 97.0 & 89.8 & 86.8 & 87.1 & 86.1 & 93.6 & 92.1 & 92.3 & 91.7 \\
\hline $40-44$ & 96.9 & 96.3 & 96.1 & 95.8 & 91.4 & 91.6 & 92.3 & 90.9 & 94.1 & 94.0 & 94.2 & 93.4 \\
\hline $45-49$ & 93.6 & 94.5 & 94.1 & 94.7 & 91.9 & 90.5 & 91.5 & 91.6 & 92.7 & 92.5 & 92.8 & 93.1 \\
\hline $50-54$ & 88.3 & 89.5 & 90.4 & 90.8 & 78.2 & 82.1 & 83.5 & 87.4 & 83.2 & 85.7 & 86.9 & 89.1 \\
\hline $55-59$ & 71.1 & 77.9 & 76.9 & 82.8 & 26.0 & 34.6 & 33.3 & 49.0 & 47.4 & 55.3 & 54.2 & 65.4 \\
\hline $60-64$ & 26.6 & 30.3 & 24.1 & 34.4 & 12.3 & 14.1 & 13.0 & 12.9 & 18.8 & 21.6 & 18.1 & 23.0 \\
\hline $65-$ & 9.4 & 8.7 & 6.8 & 6.3 & 3.9 & 2.9 & 2.2 & 2.3 & 6.0 & 5.1 & 4.0 & 3.9 \\
\hline Total & 71.3 & 71.1 & 69.4 & 68.7 & 52.3 & 51.8 & 51.3 & 50.6 & 61.4 & 61.1 & 60.0 & 59.4 \\
\hline \multicolumn{13}{|c|}{ Unemployment rate: } \\
\hline $15-19$ & 10.1 & 13.8 & 32.9 & 44.6 & 13.9 & 20.3 & 43.1 & 42.2 & 11.8 & 16.5 & 37.3 & 43.6 \\
\hline $20-24$ & 5.3 & 5.7 & 13.7 & 15.8 & 8.0 & 7.3 & 13.8 & 15.7 & 6.3 & 6.4 & 13.7 & 15.8 \\
\hline $25-29$ & 3.0 & 3.7 & 6.6 & 6.4 & 8.9 & 9.4 & 13.0 & 11.7 & 5.3 & 5.9 & 9.1 & 8.5 \\
\hline $30-34$ & 3.1 & 3.2 & 5.1 & 4.2 & 5.9 & 7.5 & 12.1 & 10.9 & 4.4 & 5.1 & 8.1 & 7.0 \\
\hline $35-39$ & 2.5 & 3.5 & 5.6 & 4.5 & 4.2 & 4.8 & 9.7 & 9.3 & 3.3 & 4.1 & 7.5 & 6.7 \\
\hline $40-44$ & 2.3 & 3.2 & 5.2 & 4.9 & 3.8 & 4.3 & 7.6 & 8.0 & 3.0 & 3.8 & 6.4 & 6.4 \\
\hline $45-49$ & 2.5 & 2.8 & 5.2 & 5.7 & 2.9 & 4.0 & 6.4 & 7.4 & 2.7 & 3.4 & 5.8 & 6.5 \\
\hline $50-54$ & 1.6 & 2.6 & 5.2 & 6.1 & 2.6 & 3.5 & 7.5 & 9.0 & 2.1 & 3.0 & 6.3 & 7.6 \\
\hline $55-59$ & 1.8 & 2.5 & 4.5 & 5.3 & 4.5 & 3.6 & 5.2 & 6.5 & 2.6 & 2.9 & 4.8 & 5.8 \\
\hline $60-64$ & 6.9 & 4.9 & 3.9 & 2.0 & 7.3 & 6.7 & 7.5 & 5.3 & 7.0 & 5.6 & 5.3 & 3.0 \\
\hline $65-$ & 5.3 & 3.5 & 3.4 & 2.8 & 5.4 & 3.5 & 6.5 & 3.3 & 5.4 & 3.5 & 4.5 & 3.0 \\
\hline Total & 3.4 & 3.9 & 6.7 & 6.5 & 5.4 & 5.9 & 9.9 & 9.8 & 4.3 & 4.8 & 8.1 & 7.9 \\
\hline
\end{tabular}

Source: Labour Force Surveys.

In observing more closely the composition of the rate of economic activity and unemployment by age (Table 2), we can see marked trends. The rate of economic activity of young people is on a sharp decline due to their longer period of education (the trend is more complicated among women due to declining fertility rates and the postponement of having children). However, the unemployment of young people is also increasing, due to their problems with finding their first job. On the other end of the age profile, the activity rate is increasing for both men and women close to their retirement age (55-59 for women, 60-64 for men), which corresponds to the period preceding the 
statutory termination of their economic activity. For even older persons, we can observe a stagnant level of activity among women and a decline among men.

The statutory retirement age is slightly increasing with current limit 63 years of age with a perspective to increase it further up to 65 years. However, the prevailing wish among the Czech population is to keep the current state. Only $30 \%$ of people - without regard to their age - agree with increasing the retirement age to better correspond to longer life expectations and better health status (CVVM, March 2006). Ever since a generous early retirement scheme was introduced in 1997, its use became very popular and increasingly represented a considerable percentage of all pensions allotted, reaching $60 \%$ of all old-age pensions in 2000 and 2001 . In consequence, the softer option of early retirement with temporarily reduced benefits was abolished in 2004 . $^{3}$

The problem is not simply the unwillingness of older people to continue working. One-third of persons searching for a new job in the period ten years before retirement declared to experience age discrimination. In $2003,45 \%$ of persons $50-59$ and $40 \%$ of persons 60-69 were worried about the possible loss of their current job. Older people feel much more affected by job loss than younger cohorts. At the same time, they are also less optimistic about assistance from the labour office - more than half of persons over 50 years of age expect to rely only on financial support, if not anything (Vidovičová, 2005).

The OECD study (2004) focused on the problem vigorously. ${ }^{4}$ It stated that the process of population ageing is far more pronounced in the CR than in most other OECD countries and that, at the same time, people exit the labour market relatively early. Experts recommended reduced work disincentives built into welfare system, strengthening the activation stance of employment programmes and improving skills and the employability of older workers. Attitudes and perceptions towards older workers have to change as well. The recommendation has had apparently no effect on policies and attitudes on various levels.

For policy reasons, the Employment Act enumerates the following categories of persons who require special attention: disabled people, adolescents who have completed only primary school, people leaving secondary schools and universities and entering their first job, jobseekers over 50 years of age and workers made redundant due to restructuring, jobseekers without qualification, jobseekers registered longer than 6 months; citizens requiring special assistance, and inadaptable citizens (Večerník, 2001).

Often, negative characteristics tend to accumulate. For instance, according to surveys made by the RILSA in $1998-2002,44 \%$ of disabled workers have only primary education, $70 \%$ are aged over 40 years, $68 \%$ were registered more than once by the labour office, and $30 \%$ are long-term unemployed. The so-called inadaptable citizens constitute an extreme category (those with underdeveloped or poor work/social ethics, frequent changes of employment, criminal offences). This group of citizens is

3 The Pension Insurance Act introduced two possibilities: 1. permanently reduced early retirement for all workers after 25 years of pension insurance, but not earlier than three years before the legal retirement age; 2 . temporarily reduced benefits solely for long-term unemployed also after 25 years of pension insurance, but not earlier than two years before the legal retirement age.

4 The present author was one of the two local experts who cooperated in drafting this OECD study. 
especially composed of young Roma educated in welfare dependent families who perceive their dependency status (often compensated by illegal business activities) as a standard way of life.

\section{Policy Perspective}

In the first phase of transition, labour offices were established and became quite successful in mediating labour opportunities, facilitated by the generally low unemployment rate and the relatively high availability of jobs. The number of persons trained or subsidized in employment peaked in 1992 but has decreased since, either because of permanently low unemployment or a lack of activity on the part of labour offices. When the unemployment rate started to rise in 1997, employment policy costs also increased, surpassing previous highs. The two reasons were rise in unemployment and the interventionist strategy of the Social Democratic government.

During 1998-1999, the first National Plan of Employment was elaborated by the Ministry of Labour and Social Affairs (MLSA), which adopted EU directives for employment policy. Four comprehensive pillars supporting employment were elaborated and were further developed in subsequent National Action Plans of Employment:

- Support for the employability of human resources (increasing skills and motivation for job searching instead of claiming welfare).

- Support for businesses and employers (improved conditions for SMEs and revitalization of several large firms, fair competition and attraction of investors).

- Flexibility of the labour market (flexible organization of work, motivation of employers to enhance skills of employees).

- Removing all discrimination (by age and gender, creating conditions for affirmative action in favour of disfavoured categories).

The share of active labour market policy (ALMP) measures of the total employment policy expenditures increased from 14\% in 1997 up to 37\% in 2006 (0.17\% of GDP). The figures also include investment incentives introduced by the 2000 amendment of the Employment Act, which are intended to support job creation and the possibility for employers to require the partial reimbursement of retraining costs for their personnel. Standard ALMP policies such as subsidised employment, public works and training programmes were complemented by obligatory Individual Action Plans (IAPs), offered to persons up to 25 years of age and to university graduates during the two year period after graduating (but only up to 30 years old).

According to the Strategy for Economic Growth, elaborated in 2005, the current ALMP system is not sufficiently motivating, and retraining has only a short-term effect. Direct financial support for job creation is considered the least effective form of support. Programmes for more complex and targeted retraining need to be supported, particularly by focusing on basic work skills and computer literacy. An efficiency assessment ought to be carried out by independent bodies. Access to information should be improved by forging ties between the MLSA and the Ministry of Education.

ALMP measures can have only moderate effect in situation when some basic problems persist: 
- Jobs are still far too costly for employers (due to the high payroll tax, which reaches $47.5 \%$ of wages).

- Despite the continuing rise of the minimum wage, the unemployment trap is too attractive for low-wage categories, as the reservation wage of the long-term unemployed remains closer to the economy's average wage.

- The labour force is not very flexible (vocational and specialized schooling is stressed over a more general education) and workers are not very territorially mobile (due to rigid attitudes and the absence of a sizable rental market).

- The development of regional frameworks and the involvement of local authorities in the job creation and job retention process are rather weak.

- Balance between family and working life is not improving and the conditions for women's return to the active labour force are often difficult.

In comparison with quite tough insurance-related benefits, quite generous conditions of provision of the state social support benefits curb incentives for individuals to seek out job opportunities. Although the living minimum has stagnated between 2002 and 2004 (because conditions for its valorisation have not been met) while the minimum wage has increased by $12 \%$ during that time, the unemployment trap remained relatively inviting (see Table 3 ). ${ }^{5}$ Not only the gap between low wages and social benefits is important, but also work conditions, territorial accessibility of the job and its costs matter. A crucial factor is informal economy, rarely taken into account in research and policy reforms.

Table 3

Wage and Benefits Levels in 1991-2006 (\% average wage)*

\begin{tabular}{|l|r|r|r|r|r|r|r|r|r|r|}
\hline \multicolumn{1}{|c|}{ Indicator } & $\mathbf{1 9 9 1}$ & $\mathbf{1 9 9 2}$ & $\mathbf{1 9 9 4}$ & $\mathbf{1 9 9 6}$ & $\mathbf{1 9 9 8}$ & $\mathbf{2 0 0 0}$ & $\mathbf{2 0 0 2}$ & $\mathbf{2 0 0 4}$ & $\mathbf{2 0 0 5}$ & $\mathbf{2 0 0 6}$ \\
\hline Minimum wage & 52.7 & 47.4 & 31.4 & 25.4 & 22.4 & 31.2 & 35.9 & 37.1 & 37.8 & 39.6 \\
\hline Unemployment benefit & 50.6 & 29.1 & 32.9 & 28.6 & 25.2 & 26.1 & 25.4 & 25.4 & 29.3 & 28.7 \\
\hline $\begin{array}{l}\text { Subsistence amounts for } \\
\text { single adult }\end{array}$ & 55.1 & 45.8 & 39.1 & 35.5 & 36.2 & 34.6 & 33.0 & 29.2 & 29.9 & 28.3 \\
\hline $\begin{array}{l}\text { Subsistence amounts for } \\
\text { family of four** }\end{array}$ & 181.4 & 150.7 & 127.7 & 112.7 & 111.2 & 103.1 & 96.3 & 85.4 & 86.3 & 81.1 \\
\hline $\begin{array}{l}\text { Net minimum wage in \% } \\
\text { of subsistence amount for } \\
\text { single person }\end{array}$ & 106.0 & 87.6 & 80.5 & 69.6 & 97.2 & 114.9 & 123.9 & 133.1 & 152.0 \\
\hline
\end{tabular}

* Only the minimum wage is related to gross average wage, all other items are related to net wage, estimated on family expenditures data by the Ministry of Labour and Social Affairs.

** Two adults and two children 10-15 years old.

Source: Ministry of Labour and Social Affairs.

5 The minimum wage surpassed the living minimum for a single adult already in 2000, and its relative value has continued to improve, currently standing 52 percentage points above the living minimum amount for the single adult. 
Inviting welfare dependency is especially advantageous to the Roma population. In recent years, many Roma have been replaced by foreign workers in their traditional jobs. They are also often discriminated against. As social benefits increase steeply with the number of offspring, children are sometimes considered as breadwinners for the whole family. No control is applied to how families actually spend social benefits, even those intended for children. The occurrence is particularly higher in regions with above-average unemployment, such as North-West Bohemia and North Moravia.

Important changes were introduced since 2005. School leavers can no longer be registered as unemployed, and if they are not successful on the labour market, they are supposed to take a subsidized job or gain further job. Measures have already been enacted that advantage working persons over those not working, such as tax credits. The new benefit system introduced in January 2007 is expected to support work motivation by the possibility to reduce or even withdraw benefits in the case of the lack of activity or non-cooperative behaviour on the part of recipients. At the same time, those working for the minimum wage will be further entitled to social benefits. For calculating benefits, only $70 \%$ of earnings will be counted for consideration of material need.

Regarding education and training, the new Act on Employment (in force since October 2004) expanded access to training for all interested persons. Labour offices can also pay for the course for people other than registered job seekers. Instead of establishing a systematic approach to further education, the relevant legislation deals only with the issue of the verification and recognition of the results of various forms of education (Act on the Recognition of Professional Qualifications, in force as of May 2004). According to an April 2006 report of the National Training Fund, the Czech Republic ranks 21 st among the EU-25 in terms of participation in further education programmes $(30 \%$ of the population participates in such programmes compared to the $42 \%$ EU average). The unemployed and people with low qualifications fare the worst in terms of access to further education programmes.

\section{Flexibility on the Labour Market: between Formal and Informal Spheres}

Under communism, labour stability was required and rewarded. Working in dependent employment, full time, with open-ended contracts and during regular working hours is a lasting legacy of the communist period. People paralleled the system by their informal and domestic activities having been pushed to private flexibility. Under market regime, new forms of economic activity and work contracts have appeared and expanded. Emphasis is placed on enhancing one's adaptability and flexibility through broad skills, multi-task jobs, flexible contracts and hours, and the ability to commute or migrate to places with available jobs.

Labour statistics record only some types of flexible arrangements. That data can be complemented by other sources, particularly household surveys. The survey "Social Situation of Households" of 2001 has brought the most complete picture available in current statistics (see Table 4). However, there are several hidden forms of flexible labour, which combine formal and informal activities in various blends. This continues the experience from the communist period when people learned to seek alternative ways to make a living. The following analysis describes some of the flexible arrangements in use today. 
Table 4

Various Characteristics of Employed by Sex, Age Group and Education in 2001 (\%)

\begin{tabular}{|l|r|r|r|r|r|r|r|r|}
\hline \multirow{2}{*}{ Characteristic } & \multicolumn{4}{|c|}{ All employed } & \multicolumn{3}{|c|}{$\begin{array}{c}\text { Of them: having secondary or } \\
\text { tertiary education }\end{array}$} \\
\cline { 2 - 10 } & \multicolumn{1}{|c|}{ Men of age } & \multicolumn{1}{|c|}{ Women of age } & \multicolumn{2}{c|}{ Men of age } & \multicolumn{2}{|c|}{ Women of age } \\
\cline { 2 - 9 } & $\mathbf{2 4 - 4 9}$ & $\mathbf{5 0 - 6 4}$ & $\mathbf{2 4 - 4 9}$ & $\mathbf{5 0 - 6 4}$ & $\mathbf{2 4 - 4 9}$ & $\mathbf{5 0 - 6 4}$ & $\mathbf{2 4 - 4 9}$ & $\mathbf{5 0 - 6 4}$ \\
\hline Main job: & & & & & & & & \\
\hline Employer & 6.1 & 5.5 & 2.8 & 2.6 & 8.5 & 9.6 & 3.7 & 3.9 \\
\hline Self-employed & 15.0 & 12.4 & 8.4 & 7.4 & 15.1 & 13.0 & 9.4 & 9.0 \\
\hline Open-ended FT & 67.0 & 69.2 & 71.3 & 73.1 & 66.7 & 67.9 & 71.6 & 73.4 \\
\hline Open-ended PT & 0.8 & 1.1 & 3.5 & 3.0 & 0.8 & 1.1 & 2.5 & 2.5 \\
\hline Temporary FT & 9.6 & 8.0 & 11.3 & 8.0 & 7.8 & 5.9 & 10.3 & 9.1 \\
\hline Temporary PT & 0.2 & 1.5 & 0.9 & 3.3 & 0.1 & 1.1 & 0.9 & 1.5 \\
\hline Other forms & 1.3 & 2.3 & 1.8 & 2.6 & 1.0 & 1.4 & 1.6 & 0.6 \\
\hline Total & 100.0 & 100.0 & 100.0 & 100.0 & 100.0 & 100.0 & 100.0 & 100.0 \\
\hline Second job: & 6.9 & 6.7 & 4.8 & 5.4 & 10.0 & 10.7 & 7.0 & 7.4 \\
\hline
\end{tabular}

Notes: FT =full-time job, PT=part-time job.

Source: Social Situation of Households 2001.

Self-employment in the CR is above the EU average - 18\% against $15.6 \%$ in 2005 (Employment in Europe, 2006). Recent data on the number of self-employed are equivocal. LFS data report an increase in self-employment until 2003, and a decrease in $2004-2005$ (together with employers, this amounted to 778 thousand in 2003, 728 thousand in 2005 but 747 thousand in 2006). Czech Administration of Social Security also reports a decrease in the total number of self-employed, but also an increase in those obliged to pay the advance for pension insurance, i.e. persons having self-employment as their main job ( 740 thousand in September 2005). This suggests that the change in tax legislation has led to more frequent terminations of self-employment as only occasionally performed work.

In fact, self-employment is much more used as part-time than full-time activity. In early 1990s, about one-quarter of non-pensioners households declared some income from self-employment based upon a business license. Until late 1990s, the share of households with a person possessing business licence increased to $40 \%$. Among those households, those declaring self-employment as their only source of income was about $12 \%$; those declaring self-employment as the main source of income was about $33 \%$; and $42 \%$ declared self-employment as only a complementary source of income. The remaining $12 \%$ declared no income from self-employment, even despite having a business license (EEA).

Part-time jobs in the CR are used only to a small extent: $4.9 \%$ in contrast to the 18.4\% EU average (Employment in Europe, 2006). Among the declared reasons for having a part-time job in the CR, are employers' objectives (lack of work to be performed) in one-fifth of respondents' cases, especially among women. But most of the reasons for not working full-time are on the side of the employees: men frequently 
declare health reasons and continuing education, while women usually stress child care (LFS). For both older men and women, temporary part-time contracts are much more frequent in comparison with the prime-aged population.

Fixed-terms contracts are used by $8.6 \%$ of workers in the CR compared to the $14.5 \%$ EU average (Employment in Europe, 2006). Unlike part-time work, fixed-term contracts are less frequent among older employees - in particular full-time jobs - which might indicate some discrimination in this regard. Older women with secondary and tertiary education more frequently have temporary jobs. The prevalence of those jobs among older workers is tied to a selection effect that prefers tertiary educated persons to remain in the labour force at a higher age.

Second jobs are not registered in their entirety. According to LFS, 250 thousand workers declared a second job in 1993 but 133 thousand in 1999 and 115 thousand in 2005 (a decline from $5.2 \%$ to $2.2 \%$ of the labour force). However, in sociological surveys, as much as one-third of economically active persons declared a supplementary activity. Of those persons, about 30\% declare to have a second job, $30 \%$ are self-employed and the remainder have supplementary earnings in some "other" way (EEA). Those include unreported and mostly untaxed regular activities such as manual work, trade and consultancy, as well as many irregular activities.

Information reported by sociological surveys reveals that the flexibility of the labour market has rather stagnated (Table 5). In terms of time flexibility, economically active people have their hours set for them by their employers more in 2005 than in 1997. Regarding workplace flexibility, more people also report that their work is fixed to one site away from home. But the flexibility of contracts has remained stable in the average, which summarizes opposite developments among men and women. All of these results are rather surprising given the fact that the percent of self-employed persons in survey samples (together with entrepreneurs) has increased over time: from $11 \%$ in 1997 to about $14 \%$ in 2001 and 2005 .

Thus we can assume that the main segment of flexibility remains hidden in several practices in the interface between the formal and informal economy. These include:

- Informal payments (particularly frequent in catering), when only a low wage is paid officially and the rest is given in cash, according to discretion of the employer (thus avoiding payroll tax for both sides).

- Hiring workers with business licences, when employers enlist workers who have a "business licence" (again avoiding payroll tax and work contract requirements). The possession of a business license is a must for employment in many private firms. ${ }^{6}$

- Hiring foreigners, especially for hard manual work (typically Ukrainians). Those people perform unskilled jobs in construction and agriculture, in hypermarkets and in textile manufacturing for less than the minimum wage, moreover often under slavery conditions. ${ }^{7}$

6 The practice is well-known in the country and referred to as the "Švarc system," the name of the entrepreneur who introduced it. Following the new Labour Code valid since 2007, such a practice is not forbidden any more.

7 Employers avoid the Labour Code and wage tariffs via the client system, which the International Organization for Migration described as "... the world governed by informal rules generated in the 
- Using a contracting agency to provide labour, without any obligation on the employer's part; the practice widely used, especially in construction where foreign (again mostly Ukrainian) workers are supplied as cheap labour by their agents operating on the brink of the law.

Table 5

Flexibility of Time, Location and Work Contract in 1997 and 2005 (\%)

\begin{tabular}{|c|c|c|c|c|c|c|}
\hline \multirow{2}{*}{ Criteria } & \multicolumn{3}{|c|}{1997} & \multicolumn{3}{|c|}{2005 (2001) } \\
\hline & Men & Women & Total & Men & Women & Total \\
\hline \multicolumn{7}{|l|}{ Who decides about working hours: } \\
\hline employer only & 50.0 & 61.0 & 55.0 & 53.7 & 64.7 & 58.7 \\
\hline the person partly & 33.6 & 28.1 & 31.1 & 29.8 & 25.4 & 27.8 \\
\hline the person fully & 13.1 & 7.4 & 10.5 & 15.7 & 7.1 & 11.8 \\
\hline can't choose & 3.3 & 3.5 & 3.4 & 0.8 & 2.7 & 1.7 \\
\hline Total & 100.0 & 100.0 & 100.0 & 100.0 & 100.0 & 100.0 \\
\hline \multicolumn{7}{|l|}{ Usual location of work: } \\
\hline one place away from work & 64.2 & 85.7 & 74.1 & 82.3 & 90.3 & 86.0 \\
\hline at home & 4.0 & 1.3 & 2.8 & 4.4 & 4.4 & 4.4 \\
\hline partly away/partly home & 7.3 & 5.6 & 6.5 & 4.6 & 3.9 & 4.3 \\
\hline in a variety of places & 21.9 & 3.9 & 13.7 & 8.3 & 0.7 & 4.8 \\
\hline can't choose & 3.3 & 3.5 & 3.4 & 0.4 & 0.7 & 0.5 \\
\hline Total & 100.0 & 100.0 & 100.0 & 100.0 & 100.0 & 100.0 \\
\hline \multicolumn{7}{|c|}{ Work contract (for employees only): } \\
\hline no written contract & 2.1 & 1.0 & 1.6 & 1.2 & 1.1 & 1.1 \\
\hline fixed-term less than 12 months & 6.3 & 3.3 & 4.9 & 9.5 & 12.4 & 10.9 \\
\hline fixed-term one year or more & 7.1 & 7.1 & 7.1 & & & \\
\hline open-ended contract & 81.5 & 85.7 & 83.5 & 86.0 & 83.7 & 84.9 \\
\hline can't choose & 2.9 & 2.9 & 2.9 & 3.3 & 2.8 & 3.1 \\
\hline Total & 100.0 & 100.0 & 100.0 & 100.0 & 100.0 & 100.0 \\
\hline
\end{tabular}

Unfortunately, in the ISSP 2005 module, the questions on place and contract flexibility were not repeated. Therefore, we used similar questions posed in the 2001 HWF survey. This data are marked by italics.

Source: ISSP "Work Orientations" 1997 and 2005; HWF survey 2001. Employed persons only.

Attitudes towards flexibility requirements obviously differ on the two sides of labour contract. Trade unions view job flexibility as only serving the interests of employers, and emphasize other principles such as avoiding job security risks and maintaining the dignity of employees. The stance of employers is that labour and employment legislation is predominantly on the side of employees and that amendments to the legislation only strengthen the imbalance. In their view, the procedure for firing employees is long, difficult and costly. Small entrepreneurs are especially reluctant to hire school-leavers, who are perceived as having a lack of skills, while making high demands in terms of earnings and other conditions.

environment of black economy of former USSR with all the techniques and criminal practices" (IOM 2005). 
In theory, legal norms do not pose any serious barriers for labour to smoothly adjust to market conditions - they only make the procedure more difficult for both parties. In practice, because of limited law enforcement, employers can evade the legal rules with their employees. For example, employees are sometimes required to work in exceedingly poor conditions or accept more overtime than the law allows; hiring and firing often do not respect the legal procedures. Multinational commercial chains also avoid regulations and set their own rules of work organization and job treatment. As mentioned above, small entrepreneurs circumvent labour law by means of various tricks.

At the same time, employers' arguments about employees' low reliability and weak loyalty are partly grounded in fact. Only a half of employees said that they are willing to work harder for the success of their firm, and only $40 \%$ declared that they are proud to work for it. Even so, only slightly more than one-fifth would not be attracted by a higher salary, even if it were to be a small raise. In cross-national comparison, Czech employees belong among those least loyal and reliable for their employers (Večerník, 2004). Similarly, the intrinsic value of work and having a job are not appreciated in the country, unlike earnings and other material advantages. All those figures have worsened over time (Večerník, 2006).

\section{Major Issues Still Pending}

Despite voluminous information available regarding the labour force and labour market, the data is too dispersed and inconsistent to analyse current trends and possible future problems from various perspectives and in-depth. Indeed, many more issues are at stake than is covered by labour statistics and sociological surveys. We would particularly need large and homogeneous datasets covering a broader area of issues and suitable for multivariate analysis. Since those datasets are not available, we can only make tentative hypotheses and highlight key issues and questions for the future. The new EU-SILC survey series is the closest to such requirements. ${ }^{8}$ Nevertheless, no single survey can provide the complete picture of the labour market and answer all open questions.

The first question is whether the future Czech economy will look more like an "assembly line" or a "laboratory." Growing FDI has been predominantly directed towards manufacturing, car production in particular. In addition to cars produced by Volkswagen's Skoda and TCPA (the alliance of Toyota, Citroen and Peugeot), Hyundai's May 2006 contract with the Czech government to make cars in North Moravia. This suggests that manufacturing will remain the cornerstone of the Czech economy. The percentage of Czechs with a university degree is still low, despite the considerable growth of students after 1989. Considering also the low levels of public support for research, this suggests that the "Czech intellect" is not keeping up to par with

8 The above mentioned survey "Social Situation of Households" of 2001 the CSO 2001 survey on Living Conditions of Households was in fact pilot survey for the programme EU-SILC (Survey on Income and Living Conditions). The survey was conducted in early 2005 and 2006 on a partly repeated random sample. The data were not available before completion the manuscript, however. 
the industrious "Czech hands". Rather than becoming knowledge-based, the Czech economy is likely to maintain its manufacturing character.

The second question relates to labour productivity and work commitment. Czech labour productivity is increasing (even at a 5\% rate last years). Like other new EU Member States, this has largely been due to the modern technologies and forms of organization that have been brought into the country by foreign companies (OECD, 2006). So far, Central Europe is attractive for Western companies given its comparative advantage of low labour costs and proximity to emerging markets. However, the work commitment of the majority of Czechs is rather low. In addition, the relationship between competencies and performance, on the one hand, and earnings and fringe benefits, on the other hand, is still far from being strong. It is thus an open question whether work efficiency can be high in the face of lax work commitment.

The third question refers to the differentiation, if not a kind of segmentation, of the labour market. In contrast to the large foreign companies, which are generously supported by investment incentives, many local SMEs struggle to survive and have not been able to make significant use of local intellectual capital or research partnerships. In a way paralleling the rigid system of higher education, which is increasingly selective on the basis of social background (Matějü, Straková et al., 2006), labour also seems to be divided between the core sector of large export manufacturing and the periphery of auxiliary firms. Also, while strategic services have developed slowly, the public administration has been expanding - which does not correspond to trends in performance or efficiency. ${ }^{9}$ In that light, a question appears whether the labour market remains fragmented or dynamically adapts to emerging economic conditions.

The fourth question concerns the cultivation of the economic environment, i.e. clear and consistent legislation accompanied by law enforcement, streamlined procedures and efficient administration. Will the state be able to tackle corruption and excessive bureaucracy, which acts as an additional "tax" on the economy? Small entrepreneurs in particular complain of the legal jungle, the lack of transparency in market competition and state support, and their uneven treatment compared to large companies. In cross-national comparison, the rigidity of the Czech labour market (regulation and the costs of hiring and firing) is not considered too high. Nevertheless, employers perceive labour legislation as not very employment-friendly and the social system as too generous, which ultimately makes low-paid jobs unattractive to unskilled local workers (see Doing Business).

Despite many problems, the Czech labour market remains quite worker-friendly. During the transition, newly introduced "hard" labour market conditions were assumed to lead to more demanding criteria and more intensive work performance. However, the coincidence of the experience people were accustomed to from the past and the "velvet conditions" of the early transition led many people to maintain the belief that the state is responsible for jobs and work opportunities. Values surveys report that the importance ascribed to self-fulfilling aspects of work is rather low and decreasing and that people

9 Strategic services such as customer support, consultancy centres, software and information development, and applied research were only recently involved in the government's investment incentive programmes. In 2005, the proportion of investments in production and strategic services was $35: 65$ in the CR compared with 56:44 in the EU as a whole. 
prefer employee security to the challenges of self-reliance and entrepreneurship. Rising stock of long-term unemployed refers to both the rigidity of the labour market and easy conditions of welfare dependency.

The new measures introduced since 2005 and since 2007, are rather insufficient to enhance motivation to work instead of welfare dependency. Moreover, to put already accepted changes into practice might be difficult. Labour offices are understaffed and can only formally comply with new forms of activation and the possibility to withdraw the benefits in cases of non-cooperation on the side of job seekers. Instead of harmonized approach, benefits are provided separately by labour offices (State Social Support) and municipalities (Social Assistance). Instead of benefit reduction, mandatory spending on social protection is rising. Instead of local job seekers, foreigners take often vacant jobs. While the overall unemployment rate is on a decrease, very long-term unemployment (two years and more) is climbing. All that is not a good investment for the future when a slowdown of economic growth might come.

\section{Referencess}

Doing Business. Washington : The World Bank 2003, 2004, 2005, www.doingbusiness.org.

Employment in Europe 2006 (2006), Brussels : European Commission.

Eyal, G., Szelenyi, I., Townsley, E. (1998), Making Capitalism without Capitalists. The New Ruling Elites in Eastern Europe. London : Verso.

IOM (International Organization for Migration) 2005. Pilot Research of the Environment of Trafficking in Human Beings on the Territory of the Czech Republic.

Matějů, P., Straková, J. et al. (2006), Unequal Chances to Education. Educational Inequalities in the Czech Republic. Praha : Academia (in Czech).

MIčoch, L. (1995), "The Restructuring of Property Rights through the Institutional Economist's Eyes." Prague Economic Papers, 4, pp. 148-158.

National Action Plans on Employment. Prague : The Ministry of Labour and Social Affairs 2004-2006.

OECD (2000), Economic Surveys. Czech Republic. Paris : OECD.

OECD (2004), Ageing and Employment Policies. Czech Republic. Paris : OECD.

OECD (2005), Economic Outlook. Paris : OECD.

OECD (2006), Economic Outlook. Paris : OECD.

Sirovátka, T., Mareš, P. (2003), Labour Market, Unemployment and Social Policy. Brno : Masaryk University, Faculty of Social Studies (in Czech).

Stark, D. (1992), "The Great Transformation? Social Change in Eastern Europe." Contemporary Sociology, 21, pp. 299-304.

Strategy for Economic Growth. Prague : The Office of the Governments of the Czech Republic, June 2005.

Večerník, J. (2001), "Labour Market Flexibility and Employment Security: Czech Republic." ILO Employment Paper No. 27.

Večerník, J. (2004), "Skating on Thin Ice: A Comparison of Work Values and Job Satisfaction in CEE and EU Countries." International Journal for Comparative Sociology, 44 (5), pp. 444-471.

Večerník, J. (2006), "Work Values and Attitudes in the Czech Republic between 1997 and 2005“. Czech Sociological Review, 42 (6), pp. 1219-1240.

Vidovičová, L. (2005), Ageism: Introduction to the Theory and Prevalence of Discriminatory Attitudes in Selected Areas. Brno: RILSA (in Czech). 


\section{Surveys used as datasets:}

ISSP modules on Work Orientations 1997 and 2005

Surveys of the international research project, which originated in 1983. The ISSP modules on Work Orientations were conducted in the Czech Republic in September 1997 by the agency STEM and by the agency SC\&C in May 2005. Data files from all countries are archived by the Zentralarchiv für Empirische Sozialforschung at the University of Cologne.

Working Conditions, 2000

Survey made by agency STEM/MARK for the MLSA in September 2000 on a quota sample of 1029 economically active persons over 15 years of age. The questionnaire copied the one applied by the European Foundation for Improvement of Living and Working Conditions in international survey.

Households, Work and Flexibility (HWF) 2001

The survey was made within the EU $6^{\text {th }}$ FP project Households, Work and Flexibility (HWF) where the Czech Republic, Hungary, Slovenia, Bulgaria, Romania, Great Britain, the Netherlands and Sweden participated (see www.hwf.at). Czech survey was conducted by the agency STEM in Spring 2001 on a random sample of 1556 persons aged 15-64.

Social Situation of Households

A survey conducted by the Czech Statistical Office following the Eurostat's recommendations in May-June 2001 on a sample of 10,870 households (re-weighted for the entire population). In addition to household characteristics and income, various opinions on well-being and employment were also questioned.

The World and European Values Study

The surveys started in 1978. The former Czechoslovakia and eight other post-communist countries joined the project in its second wave in 1991. Here, we refer to the third and last wave conducted in 1999 in 27 countries.

Economic Expectations and Attitudes (EEA)

The surveys of the Czechoslovak and later only Czech population started in May 1990 and were conducted biannually in 1990-1992 and later annually (1993-1998). The data was collected by the agency STEM.

\section{Abbreviations:}

$\begin{array}{ll}\text { ALMP } & \text { Active Labour Market Policies } \\ \text { EEA } & \text { Economic Expectations and Attitudes (surveys) } \\ \text { HWF } & \text { Households, Work and Flexibility (survey) } \\ \text { IPF } & \text { Investment Privatization Fund } \\ \text { LFS } & \text { Labour Force Surveys } \\ \text { MLSA } & \text { Ministry of Labour and Social Affairs } \\ \text { RILSA } & \text { Research Institute of Labour and Social Affairs of the MLSA } \\ \text { STEM } & \text { Centre for Empirical Surveys (agency) }\end{array}$

